ing death; to which she unhesitatingly replied, "To the best of iny knowledge I really did swallow, ut twice, altogether more than half a tablespoonful, expecting it would very soon kill me."

I once related a case, (Lancet, vol. 1, 1836-1837, page 401 ,) in which a girl was seen drinking thirty grains of the red nitric oxide of mercary, from which she recorered, as I thought, from the use of the stomach-pump.

March 20th. The favourite brother of the girl who took arsenic, told me to-day that, agreeably with my request, he has endeavoured to elicit the truth from her, and that be believes she has stated simple facts.

August 5th. To-day I was sent for to see the girl, whom $I$ found pregnant by the man on whose account she took arsenic. Whilst alone with her I said, "You suspected pregnancy when you took the arsenic." She replied; "No; but I took the first half expecting I should soon die, and when I found I did not, I took the second quantity, thinking that would be sure to kill me."

The evideuce and symptoms are tolerably conclusive that arsenic, (balf a tuble spoonful,) was swallowed.

The stomach-pump was indirectly useful, for I think the iron would not have been taken without the dread of the pump being used; and that the sight of it produced romiting more than once. As one large teaspoonful of arsenic was retained in the stomach more than two hours, it is probable that the iron had some chemical effect upon it whilst passing through the alimentary canal.

On several occasions I tried to surprise the girl by such questions as the following:- "How did you stir arsenic in the water?" Answer, without hesitation-"With my finger."

\section{CASE OF PLACENTA PREVIA.}

By Hugh E. Walker, M.D., Surgeon, \&c., Chesterfield.

Mrs. H-w, aged 30 years, residing two miles from this town, was taken in labour of her sixth child on the 14th instant. Previous labours repriesented as difficult.

I saw her about four hours after labour had commenced, in a most alarming state of exhaustion, exhibiting in an extreme degree all the symptoms consequept upon great loss of blood. Her attendants informed me that they had removed a great quantity of clots, and her clothes and bedding were completely saturated. Soon after the accession of labour pains, flooding had come on, and still continued unabated, the quantity increasing with each pain. On making an exanianation, I found the vagina filled with clotted blood, the os uteri fully dilated, and a large portion of the placenta presenting, nearly closing the orifice of the uterus. With some difficulty I passed my tinger round the anterior edge of the placenta, to ascertain the presenting part of the child, and felt what I thought was either a ahoulder or the nates. The attempt increased the hemorrhage slightly, and fearful of further reducing the already too exhausted powers of my patient, I desisted. Having previously determined to adopt the plan of treatment lately brought before the profession by Drs. Radford and Simpson. I proceeded to remove the placenta. Introducing ing left hand, I completely. and in one mass separated the placenta, which was immediately expelled with my band into the vagina; after its complete removal, the hæmorrhage, which before was considerable, entirely ceased. At this time the pains were feeble, and not of frequent occurrence. At my next examination, I found that a hand had followed the placenta, and now presented at the os externum. With the usual precautions, version was easily accomplished, and the woman safely delivered of a still-born child. The uterus contracted with tolerable firmness, and no further hæinorrhage supervened. On the day following I found my patient comfortable, though suffering slightly from the effects of the hæmorrhage, and in a few days she was perfectly recovered.

Remarks.-This is another case exemplifying the beneficiul results of the plan of treatment above alluded to ; the hæmorrhage immediately ceasing on the separation of the whole of the placenta, notwithatanding the almost inert state of the uterus, and the unequal pressure exerted by the presenting portion of the child, decidedly proving, in my opinion, that the closure of the uterine resseis is not wholly dependent upon the mechanical efforts of the uterus.

Chesterfield, Angust 27, 1845.

\section{PROVINCIAL fledical \& Surgícal Tlournal.} WEDNESDAY, SEPTEMBER 3, 1845.

Now that the agitation connected with the settlement of the medical institutions of the country, by legislative enactment, has, for a time at least, somewhat subsided, the members of the profession will bave leisure to look into certain questions of internal reform, no less intimately connected with their prosperity, and which must sooner or later engage their attention. One of the more important among these questions is that which relates to the mode of appointing to official situations of various descriptions, and especially to charitable and other institutions intended for the relief of the sick.

It is unnecessary to remind our readers that the holding of hospital appointments was made, whether wisely or not is not here the question, one of the gronnds of selection for the Fellowship of the College of Surgeons under the new Charter. Seeing, then, the importance which is attached by a chartered public body to such appointments, it becomes a matter of the deepest import to every individual qualified practitioner that they should be neither capriciously nor unadvisedly bestowed.

We are well aware that much difficulty surrounds this question, - that serious objections may be urged against every plan that has hitherto been proposed for an improvement upon the present system,-and that perhaps the attainment of one free from all objection, is an Utopian idea. The exclusion of the subscribers to charitable institutions, most of whom are but ill-qualified to judge of the merits of candidates for medical appointments, from all share in the eleetion to such offices, were it even advisable; would be 